\title{
Remembering Betty Tillman
}

\author{
Karen Vaughn
}

Published online: 13 November 2013

(C) Springer Science+Business Media New York 2013

I first met Betty in the summer of 1978. I was attending a weeklong Liberty Fund conference that Jim organized in Blacksburg, the second in a series that was to continue for more than a decade. I had attended the inaugural conference the year before, but Betty was absent for that one. She had a heart ailment that put her in the hospital during the time of the conference. Since, at the time, I had no idea who Betty Tillman was, I was surprised by the outpouring of concern and good wishes on the part of the other participants, most of whom had either studied with Jim Buchanan and Gordon Tullock, or had spent time at the Public Choice Center over the years. It seemed evident that Betty was someone very dear to them. The following summer, the summer of 1978, I had the opportunity to discover why those who knew her regarded Betty with such affection.

At the opening conference dinner, Betty greeted everyone (including me, whom she didn't know at all) as if we were especially valued members of her family. She gave us hugs, asked how our travel had been, inquired about our spouses, and wanted to know all about our children. As a relatively new mother, I was delighted to tell her about all the cute things my two year old daughter had been doing. I was feeling guilty about leaving her for a whole week, so having Betty, a mother of three herself, as a sympathetic listener was very comforting.

As the conference progressed, and I got to see more of Betty, I was increasingly amazed by her. She seemed to be everywhere, taking care of every detail the conference required. Then I learned that her administrative side wasn't all there was to Betty. One afternoon, we were invited to tea at the Public Choice Center. We entered to find a conference table set with a tablecloth and flowers from Betty's garden, and covered with enough delicious cookies, cakes and tiny muffins to make even the Ritz-Carlton proud. As impressive as that table was, it was even more impressive when I learned that Betty not only had orchestrated the whole event, but baked all the goodies herself. She had gotten up at four in the morning to get all the baking done by teatime! To someone like me, who regards any time before

K. Vaughn ( $\varangle)$

George Mason University, 11609 Forest Hill Ct, Fairfax, VA 22030, USA

e-mail: kvaughn@gmu.edu 
seven AM as the middle of the night, her actions approached the saintly. I was later to learn that the tea was not an isolated incident. She often arose in the dark to prepare for a party or a luncheon later on that day to celebrate some festive occasion.

Over the years, first at a succession of conferences in Blacksburg, and then at George Mason University, I came to realize that Betty's motherly attitude toward the conference participants during that summer week was actually a reflection of her understanding of her role in the Public Choice Center. She was first and foremost Jim Buchanan's secretary and assistant in his work. But she was more than that. Betty was the Public Choice Center's housemother, the person who nurtured all who resided there in a way that Jim Buchanan could not. Jim valued people for their ideas and their hard work. Betty made you think that she valued you for yourself. Jim was not very tolerant of human failure; Betty seemed to understand that sympathy and encouragement made it easier to try again. Jim loved academic discussion and a good joke, but he had little patience for people's personal lives if it interfered with one's work. Betty was always interested in people's feelings, families, triumphs and difficulties. Jim provided the incredible intellectual stimulation that made the Public Choice Center such a vibrant place to work, but Betty provided the warmth and the sense of belonging that gave the intellectual environment a human context.

On many occasions, Jim said Betty was indispensable to him-that the Public Choice Center worked because of Betty. Many may have thought he said this because Betty was such a good secretary to him, helping in manuscript preparation and taking care of administrative detail. In fact, Jim knew that Betty's secretarial work was only one part of why she was valued. Betty created a nurturing environment in the Public Choice Center that allowed Jim to flourish. She was both his connection to colleagues, students and visitors and his buffer against them. They were a team, and each was indispensable to the other. 